\title{
Mechanical Performance of Alumina Reinforced with NbC, TiC and WC
}

\author{
Wilson Acchar $^{\mathrm{a} *}$, Celia Regina Ferreira da Camara ${ }^{\mathrm{a}}$, Carlos Alberto Alves Cairo ${ }^{\mathrm{b}}$, Marcelo Filgueira \\ a Post-Graduation Program of Science and Materials Engineering, \\ Federal University of Rio Grande do Norte - UFRN, CEP 59072-970, Natal, RN, Brazil \\ ${ }^{\mathrm{b}}$ Centro Técnico Aeroespacial, Divisão de Materiais, Instituto de Aeronautica e Espaço - IAE, \\ Praça Marechal do Ar Eduardo Gomes, 50, CEP 12228-904, São José dos Campos, SP, Brazil \\ 'State University of Northern Rio de Janeiro - UENF, Av. Alberto Lamego, \\ 2000, CEP 28013-600, Campos dos Goytacazes, RJ, Brazil
}

Received: March 2, 2012; Revised: May 3, 2012

\begin{abstract}
The incorporation of refractory hard particles in $\mathrm{Al}_{2} \mathrm{O}_{3}$-based composites may inhibit grain growth of the matrix, which could significantly contribute to mechanical performance of the composite. The present study aimed to investigate the potential use of $\mathrm{NbC}$ as alumina reinforcing material, as an alternative to other carbides such as TiC and WC. Alumina was mixed with a fixed carbide concentration of $30 \mathrm{wt} .(\%)$ in a ball mill and uniaxially hot-pressed at $1650{ }^{\circ} \mathrm{C}$ under a load of $30 \mathrm{MPa}$ in an inert atmosphere. X-ray diffraction revealed no oxidation products were present after the sintering process. Microstructure analyses indicate a homogeneous carbide distribution in the alumina matrix. Results obtained in this study show that alumina reinforced with $\mathrm{NbC}$ is a composite material with properties comparable to those of alumina reinforced with $\mathrm{WC}$ and TiC, thereby making it good reinforcing material.
\end{abstract}

Keywords: alumina, niobium carbide, titanium carbide, tungsten carbide, mechanical properties

\section{Introduction}

At present alumina reinforced with micro and nano-sized carbides, such as $\mathrm{TiC}^{1}, \mathrm{WC}^{2}, \mathrm{AlTiC}^{3}$ and $\mathrm{ZrO}_{2}^{4}$ represent a new class of hard materials with improved mechanical properties. The incorporation of theses reinforcing elements may also increase the wear behavior of alumina matrix ${ }^{5}$. Although the cutting tools market is still dominated by WC-Co, alumina-based composite materials may be a good alternative to improve cutting speed and lower production $\operatorname{cost}^{6}$. Adding these reinforcing elements increases strength and hardness values at room temperatures in comparison with monolithic material ${ }^{7}$. Alumina-composite materials withstand higher temperatures than WC-Co without deformation, allowing tools to cut at faster speeds. Others studies have shown the beneficial mechanical effect produced by the incorporating carbon nano-fiber $(\mathrm{CNF})^{8}$ and nanotubes $(\mathrm{CNT})^{9}$. Flexure strength increased to 1.5 vol.\% of carbon nanotubes. Greater CNT content reduces the properties of composite materials ${ }^{9}$. Although the presence of carbon nanofiber improved fracture toughness, the higher CNT content lowered the hardness and flexural strength of composite materials $^{8,9}$.

Niobium carbide exhibits good chemical properties, including a high melting point, significant levels of hardness, elevated Young's modulus and a thermal expansion coefficient compatible to alumina, making it a good reinforcing element to be added to alumina.

*e-mail: acchar@dfte.ufrn.br
Brazil holds the world's largest niobium reserves, making the study and use of niobium compounds very strategic for the country. Some research published in the literature has demonstrated the good potential for employing $\mathrm{Nb}_{2} \mathrm{O}_{5}$ and $\mathrm{NbC}$ as sintering additives ${ }^{10}$, grain growth inhibitors ${ }^{11}$ and reinforcing elements in a ceramic matrix ${ }^{12}$. Addition of $\mathrm{Nb}_{2} \mathrm{O}_{5}$ improves densification of alumina at lower sintering temperatures ${ }^{13}$. Alumina doped with niobium oxide has the disadvantage of increasing the grain size of alumina during sintering ${ }^{14}$. The presence of $\mathrm{NbC}$ causes a pinning effect very similar to incorporation of $\mathrm{TiC}, \mathrm{WC}$ or other carbides ${ }^{15}$. Incorporating $\mathrm{NbC}$ particles into alumina matrix has improved the mechanical properties of alumina-based composite materials ${ }^{16}$. Manufacturing $\mathrm{NbC/alumina} \mathrm{composite} \mathrm{materials} \mathrm{by} \mathrm{active} \mathrm{filler} \mathrm{controlled}$ polymer pyrolysis reaction has also been reported ${ }^{17}$. Results show that this process has the advantage of achieving low sintering temperatures, although composite materials display high porosity and low strength values ${ }^{16}$, in addition to niobium oxidation ${ }^{17}$. It is not possible to compare directly results described in the literature for alumina composites. Some parameters, such as alumina powder (particle size, surface energy, chemical purity), processing method (uniaxial pressing, hot-pressing, isostatic pressing) and sintering conditions (temperature and time) are somewhat different, meaning direct comparison is not accurate.

This study sought to compare the mechanical effect of each carbide (WC, TiC and $\mathrm{NbC}$ ) in an alumina matrix, using the same processing method and parameters. 


\section{Experimental Procedure}

Starting powders consisted of Alumina APC-2011 SG with surface area of $1.5 \mathrm{~m}^{2} \cdot \mathrm{g}^{-1}$ (Alcoa, Brazil,), NbC (Herman Starck, Berlin, Germany), WC (Wolfram Bergbau, Austria) and TiC (Aldrich) with D50 $=2.3 \mu \mathrm{m}, 2.0 \mu \mathrm{m}$ $1.5 \mu \mathrm{m}$ and $2.5 \mu \mathrm{m}$, respectively. $\mathrm{Al}_{2} \mathrm{O}_{3}$ containing $30 \mathrm{wt} .(\%)$ of reinforcing carbide (best results reported in the literature) was dry-mixed for 4 hours in a planetary ball mill containing alumina grinding media. Powder compacts were then uniaxially hot pressed in a cylindrical die $40 \mathrm{~mm}$ in diameter under $30 \mathrm{MPa}$ at $1650^{\circ} \mathrm{C}$ in flowing argon. Apparent density and porosity of the sintered bodies was determined using the Archimedes water displacement method. Crystalline phases present after the sintering process were identified by X-ray diffraction (Shimadzu XRD-600) in a range of 20 to 90 with a $2 \theta$ scanning rate of $2^{\circ} \mathrm{min}^{-1}$. Vickers's microhardness $\left(\mathrm{H}_{\mathrm{v}}\right)$ was evaluated by a Vickers indenter applying a load of $30 \mathrm{~N}$ during 15 seconds. Mechanical strength of the specimens (average of samples per value) was measured at ambient temperature by a universal testing machine (Zwick, $2.5 \mathrm{kN}$ ), using three-point bending geometry at a constant cross-head speed of $0.5 \mathrm{~mm} / \mathrm{min}$. Fracture surfaces were observed through by Scanning Electron Microscopy (Shimadzu SSX-550).

In order to determine the wear characteristics of composite materials, experiments were conducted in Contenco microprocessed water-cooled abrasion equipment. The equipment operates on motor power of $1 \mathrm{~kW}$, with an

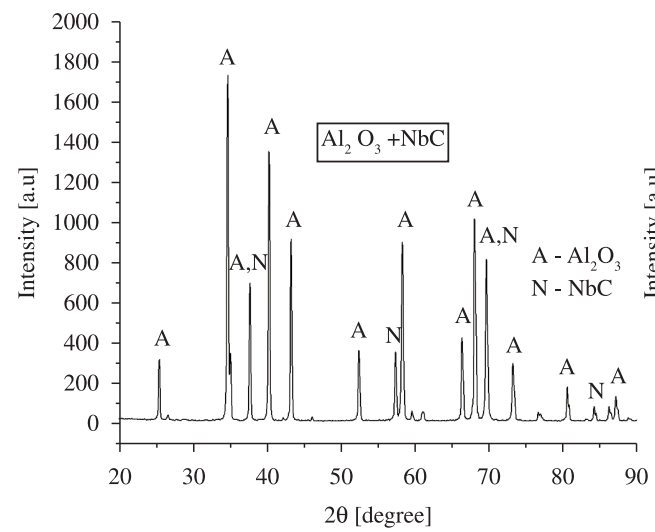

(a) axial load applied for a sample of up to $50 \mathrm{kgf}$, and constant rotation of $60 \mathrm{rpm}$. The abrasion granite has an internal and external diameter of $480 \mathrm{~mm}$ and $800 \mathrm{~mm}$, respectively. Disintegration of the granite, a hard strong rock, was carried out under conditions imitating drilling, applying loads and cutting speed found in practice. Wear intensity of the insert (composite material) as well as the granite energetic disintegration capacity can be determined by the following Equation 1:

$W_{i}=Q_{i} /\left(t_{i} \times v_{i}\right)(g / m)$

Where $\mathrm{Q}_{\mathrm{i}}$ is the insert weight loss by abrasion during the test, $t_{i}$ represents test duration and $v_{i}$ the linear cutting speed. Practical loss due to abrasion was evaluated according to the difference between weight of the insert before and after each test ${ }^{18}$.

\section{Results and Discussion}

Table 1 compares the theoretical density and porosity of reinforced composite materials. Results indicated that all hot-pressed composite materials were almost fully dense (porosity values $<0.7 \%$ ), regardless of the carbide added. Increased density values in relation to the alumina matrix are due to the higher density values of the added hard carbide particles.

Figure 1 depicts a typical X-ray diffraction pattern of the sintered alumina with $\mathrm{NbC}$ and $\mathrm{TiC}$ composite materials. Alumina and the original refractory carbides are shown to

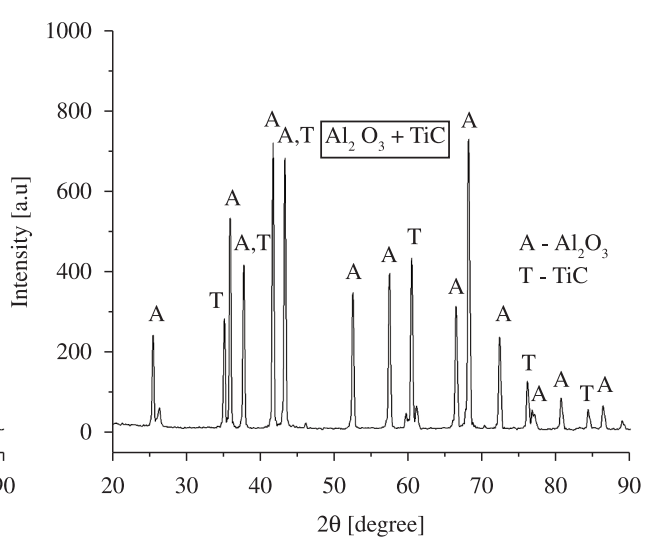

(b)

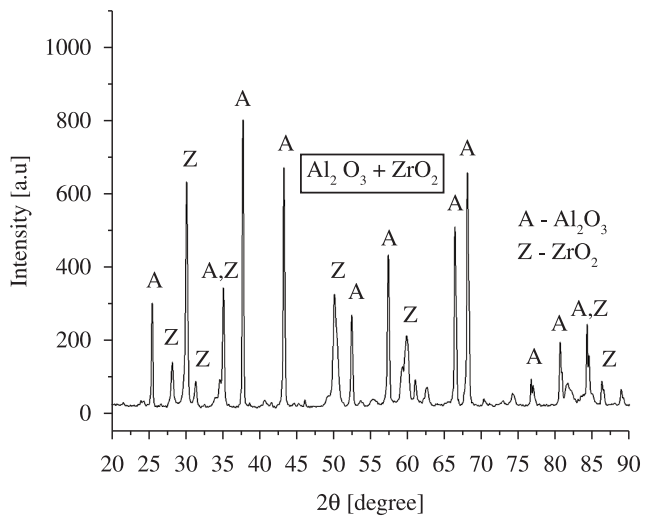

(c)

Figure 1. X-ray diffraction pattern of the sintered alumina with: a) $\mathrm{NbC}$, b) $\mathrm{TiC}$ and c) $\mathrm{ZrO}_{2}$. 
be the only crystalline phases present. No other crystalline phases were identified (Table 1). This corroborates findings reported in the literature for alumina- $\mathrm{WC}^{5}$, alumina-(W,Ti) $\mathrm{C}^{15}$ and alumina-TiC ${ }^{1}$, although not for the $\mathrm{Al}_{2} \mathrm{O}_{3}$-WC-Co composite material produced by vacuum hot pressing ${ }^{19}$. This material exhibits a new crystalline intermetallic phase $\left(\mathrm{Co}_{3} \mathrm{~W}_{3} \mathrm{C}\right)$, which is responsible for the higher hardness values recorded in this system ${ }^{19}$.

Table 2 illustrates the hardness and fracture strength obtained for composite materials, all of which used the same alumina matrix, enabling direct comparison between the different carbides. Composite materials reinforced with hard carbides exhibited no marcant differences between them, and an increase in comparison to alumina matrix. Hardness values for composite materials ranged between 22 and $24.6 \mathrm{GPa}$, significantly better as compared to pure alumina $(18,5 \mathrm{GPa})$. The hardness obtained for $\mathrm{Al}_{2} \mathrm{O}_{3}-\mathrm{NbC}$ and alumina reinforced with other carbides in the present study was also comparable with values reported in the literature for alumina- $\mathrm{TiC}^{1},(\mathrm{~W}, \mathrm{Ti}) \mathrm{C}^{7}$ and $\mathrm{WC}^{6}$ composites.

Flexural strength values are displayed in Table 2 and show a similar behavior. No significant difference was recorded for the margin of error with carbide using $\mathrm{NbC}$, WC or TiC (310-350 MPa). Results demonstrated that composite materials did not significantly change mechanical properties, indicting that type of carbide addition has no significant influence on the strength and hardness of composite material.

The strength depends basically on the presence of defects in the microstructure such as pores, agglomerates and cracks caused by the differences of the thermal expansion coefficient between matrix and reinforcing carbide. All composite materials showed analogous density after sintering process (Table 1) and also comparable thermal expansion coefficient, which can explain the comparable strength values observed.

Figure 2 depicts an SEM photograph of the surface fracture of alumina-reinforced with $\mathrm{NbC}$ and TiC. All composite materials exhibit basically the same fracture behavior. Fracture mode consisted mainly of an intergranular fracture accompanied by partial transgranular fracture. Materials display homogeneous structure and the presence of carbide particles in the alumina grain and grain boundary. Isolated pores were also found in the alumina grains.

Table 1. Density and porosity of the reinforced composite materials.

\begin{tabular}{cccc}
\hline $\begin{array}{c}\text { Initial } \\
\text { material }\end{array}$ & $\mathbf{P}[\%]$ & $\rho\left[\mathbf{g . c m}^{-3}\right]$ & $\begin{array}{c}\text { Phases identified } \\
\text { after sintering }\end{array}$ \\
\hline Alumina & 0.52 & 3.9 & Alumina \\
$\mathrm{A}+\mathrm{WC}$ & 0.5 & 4.6 & Alumina, tungsten carbide \\
$\mathrm{A}+\mathrm{TiC}$ & 0.48 & 4.3 & Alumina, titanium carbide \\
$\mathrm{A}+\mathrm{NbC}$ & 0.45 & 4.5 & Alumina, niobium carbide \\
\hline
\end{tabular}

Table 2. Mechanical properties of composite materials.

\begin{tabular}{ccc}
\hline & $\sigma_{\mathbf{F}}$ & $\mathbf{H}_{\mathbf{v}}$ \\
\hline Alumina & $280 \pm 20$ & 18.5 \\
A + WC & $310 \pm 28$ & 22.5 \\
A + TiC & $350 \pm 35$ & 23.21 \\
A + NbC & $340 \pm 30$ & 24.60 \\
\hline
\end{tabular}

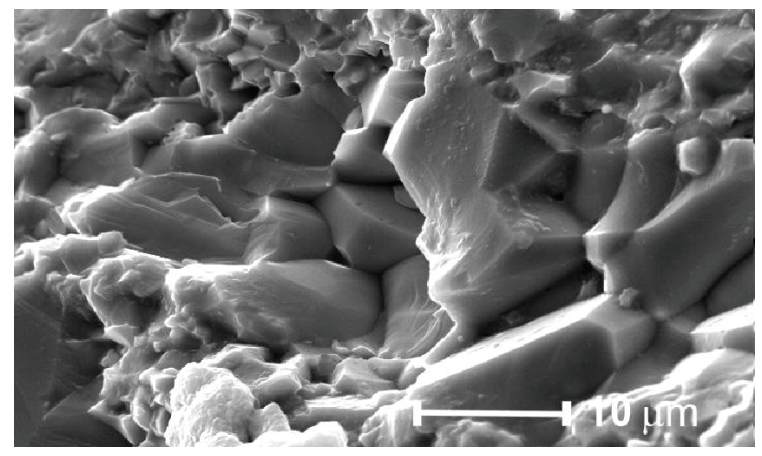

(b)

(a)

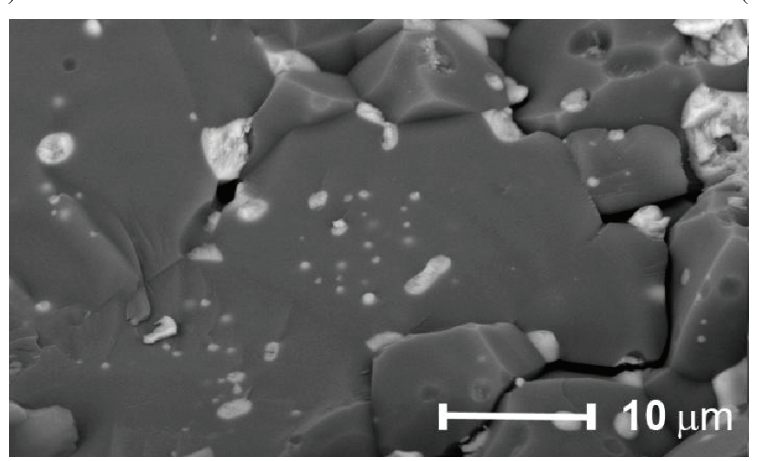

(c)

Figure 2. SEM photograph of the surface fracture of the sintered alumina with: a) $\mathrm{NbC}$ and b) $\mathrm{TiC}$ and c) $\mathrm{ZrO}_{2}$. 
Table 3. Wear behavior for the carbide-reinforced materials investigated in this work.

\begin{tabular}{ccccc}
\hline & $\begin{array}{c}\text { Initial mass } \\
{[\mathbf{g}]}\end{array}$ & $\begin{array}{c}\text { Final mass } \\
{[\mathbf{g}]}\end{array}$ & $\begin{array}{c}\Delta \mathbf{m} \\
(\mathbf{M i}-\mathbf{M f}) \\
{[\mathbf{g}]}\end{array}$ & $\begin{array}{c}\text { Wear } \\
{\left[\mathbf{m g . m} \mathbf{m}^{-1}\right]}\end{array}$ \\
\hline Alumina & 0.490 & 0.486 & 0.004 & 0.107 \\
$\mathrm{~A}+\mathrm{WC}$ & 0.980 & 0.977 & 0.003 & 0.080 \\
$\mathrm{~A}+\mathrm{TiC}$ & 1.178 & 1.176 & 0.002 & 0.053 \\
$\mathrm{~A}+\mathrm{NbC}$ & 0.781 & 0.776 & 0.005 & 0.070 \\
\hline
\end{tabular}

Table 3 shows wear behavior for the carbide-reinforced materials investigated in this study. Results indicated that incorporation of carbides promotes an increase in linear wear behavior when compared to pure alumina, while adding $\mathrm{TiC}$ and $\mathrm{NbC}$ causes a similar effect. The inclusion of $\mathrm{TiC}$ particles produces greater increases in wear behavior, with alumina material displaying a decrease in mass loss from 0.107 to $0.053 \mathrm{mg} \cdot \mathrm{m}^{-1}$. Increased wear behavior for alumina

\section{References}

1. Shi RX, Yin YS and Ge H. Toughening mechanisms and microstructure of $\mathrm{Al}_{2} \mathrm{O}_{3}$ - TiC composites. Materials Science Engineering A. 2011; 528:5341-5347. http://dx.doi. org/10.1016/j.msea.2011.03.054

2. Acchar W, Zollfarnk $\mathrm{C}$ and Greil P. Microstructure of alumina reinforced with tungs - ten carbide. Journal Materials Science. 2006; 41:3299-3302. http://dx.doi.org/10.1007/ s10853-005-5457-z

3. Zhang XH, Liu CX, Li MS, Zhang JH and Sun JL. Toughening mechanism of alumina matrix ceramic composites with the addition of AlTiC master alloys and $\mathrm{ZrO}_{2}$. Ceramic International. 2009; 35:93-97. http://dx.doi.org/10.1016/j. ceramint.2007.09.109

4. Daguano JK, Santos C, Souza RC, Balestra RM, Strecker K and Elias $\mathrm{CN}$. Properties of $\mathrm{ZrO}_{2}-\mathrm{Al}_{2} \mathrm{O}_{3}$ composite as a function of isothermal holding time. International Journal Refractory Metals \& Hard Materials. 2007; 25:374-379.

5. Jianxin D, Zeliang D, Jun Z, Jianfeng L, Tongkun C. Unlubricated friction and wear behaviors of various alumina-based ceramic composites against cemented carbide. Ceramic International. 2006; 32:499-507. http://dx.doi. org/10.1016/j.ceramint.2005.03.031

6. Brandt G. Ceramic cutting tools, state of the art and development trends. Materials Technology. 1999; 14:17-24.

7. Zhao J, Yuan $X$ and Zhou Y. Processing and characterization of an $\mathrm{Al}_{2} \mathrm{O}_{3}$-WC-TiC micronanocomposite ceramic tool material. Materials Science Engineering A. 2010; 527:1844-49. http:// dx.doi.org/10.1016/j.msea.2009.11.018

8. Maeonsiri S, Laokul P, Klinkaenarong J and Amornkitbamrung V. Carbon nano fiber- reinforced alumina nanocomposite: Fabrication andmechanical properties. Materials Science Engineering A. 2007; 447:44-50. http://dx.doi.org/10.1016/j. msea.2006.08.009

9. Kim SW, Chung WS, Sohn KS, Son Y and Lee S. Improvement of flexure strength and fracture toughness in alumina matrix composites reinforced with carbon nano-tube. Materials Science Engineering A. 2009; 517:293-299. http://dx.doi. org/10.1016/j.msea.2009.04.035

10. Hsu YF. Influence of $\mathrm{Nb}_{2} \mathrm{O}_{5}$ additive on the densification and microstructural evolution of fine alumina powders. Materials reinforced with $\mathrm{TiC},(\mathrm{W}, \mathrm{Ti}) \mathrm{C}$ and $\mathrm{SiC}$ was also observed in the literature ${ }^{5}$.

\section{Conclusions}

Dense $\mathrm{Al}_{2} \mathrm{O}_{3}$-carbides ceramic composites were obtained by hot pressing at $1650{ }^{\circ} \mathrm{C}$. The addition of $30 \mathrm{wt} .(\%) \mathrm{NbC}$, $\mathrm{TiC}$ and $\mathrm{WC}$ increases the hardness, flexural strength and wear behavior of the alumina matrix, improving the possibility of their use as cutting tools. The Alumina-NbC composite material shows no significant difference in mechanical properties as compared to other carbides (WC and $\mathrm{TiC}$ ), making the use of $\mathrm{NbC}$ as reinforcing element very attractive. Microstructure analyses show a homogeneous carbide distribution in the alumina matrix and the presence of a transgranular fracture mode accompanied by a partial transgranular fracture.

\section{Acknowledgement}

The authors would like to thank the CNPq for their financial support.

Science Engineering A. 2005; 399:232-237. http://dx.doi. org/10.1016/j.msea.2005.03.101

11. Huang SG, Liu L, Li L, Van der Biest O and Vleugels J. $\mathrm{NbC}$ as grain growth inhibi- tor and carbide in WC-Co hardmetals. International Journal Refractory Metal \& Hard Materials. 2008; 26:389-395.

12. Santos C, Maeda LD, Cairo CA and Acchar W. Mechanical properties of hot pressed $\mathrm{ZrO}_{2}-\mathrm{NbC}$ ceramic composites. International Journal Refractory Metals \& Hard Materials. 2008; 26:14-18.

13. Pallone EMJA, Tromboni V, Botta WJ, Tomasi FR. Synthesis of $\mathrm{Al}_{2} \mathrm{O}_{3}-\mathrm{NbC}$ by reactive milling and production of nanocomposite. Journal Materials Processing Technology. 2003; 143-144:185-190. http://dx.doi.org/10.1016/ S0924-0136(03)00411-4

14. Acchar W, Schwarze D, Greil P. Sintering of $\mathrm{Al}_{2} \mathrm{O}_{3}-\mathrm{NbC}$ composites using $\mathrm{TiO}_{2}$ and $\mathrm{MnO}$ additives: preliminary results. Materials Science Engineering A. 2003; 351:299-303. http:// dx.doi.org/10.1016/S0921-5093(02)00857-2

15. Acchar W, Greil P, Martinelli AE, Cairo CAA, Bressiani AHA and Bressiani JC. Sintering behaviour of alumina-niobium carbide composites. Journal European Ceramic Society. 2000; 20:1765-69. http://dx.doi.org/10.1016/ S0955-2219(00)00060-1

16. Acchar W, Wolf DM. Ceramic composites derived from poly (phenylsilsesquioxane/ $\mathrm{Al}_{2} \mathrm{O}_{3} / \mathrm{Nb}$. Materials Science Engineering A. 2005; 396:251-254. http://dx.doi.org/10.1016/j. msea.2005.01.018

17. Dernovsek O, Bressiani JC, Bressiani AH, Acchar W and Greil P. Reaction bonded niobium carbide ceramic from polymer-filer mixtures. Journal Materials Science. 2000; 35:2201-2207. http://dx.doi.org/10.1023/A:1004766607619

18. Bobrovnitchii GS, Filgueira M, Monteiro S and Tardim R. Wear of diamond compo-sites applied as inserts in drilling tools. Materials Science Forum. 2010; 660-661:468-473. http:// dx.doi.org/10.4028/www.scientific.net/MSF.660-661.468

19. Tai WP and Watanab T. Fabrication and mechanical properties of $\mathrm{Al}_{2} \mathrm{O}_{3}$-WC-Co composite by vacuum hot pressing. Journal American Ceramic Society. 1998; 81:1673-76. http://dx.doi. org/10.1111/j.1151-2916.1998.tb02531.x 